\title{
HUBUNGAN OPTIMALISASI SUHU DAN WAKTU PENGGORENGAN PADA MESIN VACUUM FRYING TERHADAP PENINGKATAN KUALITAS KERIPIK PISANG KEPOK
}

\author{
RELATIONSHIP OF OPTIMIZATION OF TEMPERATURE AND TEMPERATURE IN VACUUM \\ FRYING MACHINES TO INCREASING THE QUALITY OF BANANA KEPOK CHIPS
}

\author{
Shamroz Afrozi ${ }^{*}$, Nely Ana Mufarida, S.T., M.T. ${ }^{2}$, Rohimatus Sofiyah, S.Si., M.Si. $^{3}$ \\ ${ }^{1}$ Mahasiswa, ${ }^{2}$ Dosen Pembimbing $1,{ }^{3}$ Dosen Pembimbing 2, Program Studi Teknik Mesin, Fakultas \\ Teknik, Universitas Muhammadiyah Jember \\ "E-mail : afrozikhan091293@gmail.com
}

\begin{abstract}
ABSTRAK
Perumusan masalah dalam penelitian ini yaitu membahas hubungan optimalisasi suhu dan waktu penggorengan pada mesin vacuum frying terhadap peningkatan kualitas keripik pisang. Tujuan penelitian ini adalah untuk mengkaji hubungan optimalisasi suhu dan waktu penggorengan pada mesin vacuum frying terhadap peningkatan kualitas keripik pisang kepok dan untuk memperoleh suhu dan waktu penggorengan yang terbaik dalam pembuatan keripik pisang kepok dengan penggorengan vacuum frying sehingga dapat diperoleh produk keripik pisang yang sesuai dengan keinginan konsumen. Penelitian ini dibatasi pada hal-hal sebagai berikut yaitu pengamatan suhu yang digunakan untuk melakukan penggorengan adalah $70^{\circ} \mathrm{C}, 80^{\circ} \mathrm{C}$, dan $90^{\circ} \mathrm{C}$ dan variasi waktunya adalah 30 menit, 40 menit, dan 50 menit sehingga diperoleh kualitas keripik pisangyang optimal berdasarkan uji organoleptik, Kadar air buah-buahan yang digoreng sebesar 60\% - 85\%, Kapasitas maksimal tabung penggoreng $2 \mathrm{~kg}$ dengan kebutuhan minyak goreng sebanyak 12 liter, Temperatur penggorengan dibatasi $70^{\circ} \mathrm{C}-90^{\circ} \mathrm{C}$ untuk menghindari perubahan warna dan rasa., Bahan utama olahan yang di pakai dalam penelitian ini menggunakan jenis pisang kepok. Manfaat penelitian ini adalah dibutuhkan alat Vacuum Fryer untuk dapat dihasilkan produk olahan yang tidak gosong, tampak cerah seperti warna aslinya dan kandungan vitamin dari buah olahan tidak rusak. Kerusakan aroma dan rasa dapat dihindari karena suhu penggorengannya lebih rendah dari suhu penggorengan pada tekanan satu atmosfir.

Kata kunci : optimalisasi suhu, waktu penggorengan, mesin vacuum frying, kualitas keripik pisang.
\end{abstract}

\begin{abstract}
The review of literature in this research is discussing the connection of temperature optimization and frying time on the vacuum frying machine as quality improvement of banana chips. The purpose of this research is to study the connection between temperature optimization and frying time on the vacuum frying machine as quality improvement of banana kepok chips and to obtain the best temperature and time of frying in making banana kepok chips with vacuum frying fryer so it will produced banana chips according to the consumer desire. This research is observe about the following observations: temperature observation used for frying is $70 \mathrm{oC}, 80 \mathrm{oC}$, and $90 \mathrm{oC}$ and the variation time is 30 minutes, 40 minutes, and 50 minutes so it can be use to produced optimal quality of banana chips based on organoleptic test, -food fried of 60\% - 85\%, Maximum capacity of $2 \mathrm{~kg}$ frying tube with cooking oil requirement of 12 liters, Frying temperature is limited in $70 \circ \mathrm{C}-90 \mathrm{oC}$ to avoid the changing of color and taste. The main materials used in this study are using the type banana kepok. The benefits of this research can be as a learning of the uses Vacuum Fryer tool in order to produce optimal qulity of the product, the product will looks bright as the original color and vitamin content after being processed is not damaged. The damage of flavor and taste can be avoided because the frying temperature is lower than the frying temperature at the one atmosphere pressure.

keyword: temperature optimization, frying time, vacuum frying machine, quality of banana chips
\end{abstract}

\section{PENDAHULUAN}

Buah pisang merupakan hasil samping dari pemanfaatan pisang yang dapat dijadikan makanan ringan, seperti keripik pisang. Hal ini menjadi peluang bisnis baru. Para pengusaha keripik pisang dapat memanfaatkan buah pisang menjadi olahan keripik 
pisang dengan variasi rasa yang baru. Penyajian variasi bisa dengan cara menaburkan bumbu pada pisang tersebut. Pilih bumbu tabur aneka rasa untuk memberikan sensasi rasa yang berbeda. Menurut Wijayanti (oktober 2011), alat penggorengan dengan metode vakum untuk produk olahan keripik pisang dengan suhu $80^{\circ} \mathrm{C}$ dan $90^{\circ} \mathrm{C}$ memberikan hasil yang paling baik terhadap mutu keripik pisang. Hal ini dapat memberikan alternatif teknologi untuk pembuatan keripik pisang bagi para pengusaha.

Pembuatan keripik pisang diawali dengan mengupas kulit buah pisang. Selanjutnya diambil bagian daging buahnya dan dibelah menjadi dua bagian. Kemudian potongan pisang tersebut diberi perlakuan praproses pembekuan selama minimal enam jam. Selanjutnya potongan buah pisang digoreng dengan alat penggorengan secara vakum pada suhu $85^{\circ} \mathrm{C}$, dengan tekanan sekitar $70 \mathrm{cmHg}$ selama 50 menit. Keripik adalah produk yang dihasilkan melalui tahapan pengupasan, pengirisan, dan penggorengan. Keripik banyak menyerap minyak selama penggorengan. Banyak sedikitnya minyak yang diserap akan mempengaruhi rasa, tekstur dan kondisi fisik keripik (Azkenazi N, S Mizrahi dan Z Berk. 1984. Heat and mass Transfer in frying).

Teknologi pembuatan keripik dapat melalui penggorengan manual dan vacuum frying. Penggorengan manual dapat dilakukan dengan menggunakan wajan, sedangkan penggorengan vacuum frying dilakukan dengan menggunakan mesin penggoreng hampa atau dikenal dengan vacuumfryer. Teknologi penggorengan dengan mesin vacuum fryer memiliki beberapa keunggulan daripada penggorengan manual dengan wajan. Pada penggorengan menggunakan mesin vacuum frying yang menggunakan variabel suhu untuk menentukan kualitas hasil penggorengan, biasanya digunakan untuk penggorengan pada standar suhu rendah.Kualitas tersebut mencakup dari segi warna, tekstur, aroma dan daya simpan yang lebih lama. Berdasarkan uraian tersebut maka diperlukan adanya penelitian tentang hubungan optimalisasi suhu dan waktu penggorengan yang menggunakan teknologi mesin vacuum frying terhadap upaya peningkatan kualitas keripik pisang kepok.

Berdasarkan uraian diatas terdapat permasalahan yang dihadapi yaitu bagaimanakah hubungan optimalisasi suhu dan waktu penggorengan pada mesin vacuum frying terhadap peningkatan kualitas keripik pisang.
Tujuan penelitian ini adalah untuk mengkaji hubungan optimalisasi suhu dan waktu penggorengan pada mesin vacuum frying terhadap peningkatan kualitas keripik pisang kepok, dan untuk memperoleh suhu dan waktu penggorengan yang terbaik dalam pembuatan keripik pisang kepok dengan penggorengan vacuum frying sehingga dapat diperoleh produk keripik pisang yang sesuai dengan keinginan konsumen. Penelitian ini dibatasi pada hal-hal sebagai berikut:

- Pengamatan suhu yang digunakan untuk melakukan penggorengan adalah $70^{\circ} \mathrm{C}, 80^{\circ} \mathrm{C}$, dan $90^{\circ} \mathrm{C}$ dan variasi waktunya adalah 30 menit, 40 menit, dan 50 menit sehingga diperoleh kualitas keripik pisangyang optimal berdasarkan uji organoleptik.

- Kadar air buah-buahan yang digoreng sebesar $60 \%$ - 85\%. Berdasarkan suhu di satu atmosfir. (Aguk Dewantara).

- Kapasitas maksimal tabung penggoreng $2 \mathrm{~kg}$ dengan kebutuhan minyak goreng sebanyak 12 liter.Temperatur penggorengan dibatasi $70^{\circ} \mathrm{C}$ $90^{\circ} \mathrm{C}$ untuk menghindari perubahanwarna dan rasa.

- Bahan utama olahan yang di pakai dalam penelitian ini menggunakan jenis pisang kepok.

\section{METODE PENELITIAN}

Metode penelitian yang digunakan dalam penelitian ini adalah metode experimental nyata (true experimental research). Jenis penelitian ini mempunyai tujuan untuk mengetahui hubungan yang terjadi antar faktor atau variabel-variabel yang ada, dengan cara memberi perlakuan kepada satu atau lebih kelompok eksperimental dengan kondisi perlakuan yang berbeda-beda.

\section{Alat Penelitian}

Peralatan yang dibutuhkan untuk membuat kripik pisang antara lain:
1.Baskom
2.Alas Telenan
9.Tungku atau kompor
3.Alat perajang (slicer) atau kompor gas
4.Pisau stainless steel
10.Tampah/nyiru/wadah
5.Ember plastik
6.Penggorengan
(wajan)
7.Vacuum Frying
11.Container plastik
12.Plastik Polipropilen
(PP) ketebalan 0,8
$\mathrm{mm} /$ aluminum foil
13.Label

8.Sealer

\section{Mesin Vacuum Frying}

Alat yang digunakan dalam penelitian ini adalah mesin vacuum frying kapasitas $2 \mathrm{~kg}$ bahan dengan spesifikasi sebagai berikut:

Tabel 1. Spesifikasi Mesin Vacuum Frying 


\begin{tabular}{|l|l|}
\hline Dimensi Mesin & $\begin{array}{l}9800 \mathrm{~mm} \text { x } 710 \mathrm{~mm} \text { x } \\
1150 \mathrm{~mm}\end{array}$ \\
\hline Bahan Material & $\begin{array}{l}\text { Stainless Steel Anti } \\
\text { Karat Berstandar Food } \\
\text { Grade }\end{array}$ \\
\hline $\begin{array}{l}\text { Tebal Bahan Tabung } \\
\text { Penggorengan }\end{array}$ & $2 \mathrm{~mm}$ \\
\hline Waktu Masak & 30 menit - 50 menit \\
\hline Fitur Pengontrol Suhu & $\begin{array}{l}\text { Otomatis ( Automatic } \\
\text { Thermostat Control ) }\end{array}$ \\
\hline Pemanas & $\begin{array}{l}\text { Kompor ( Tungku ) Gas } \\
\text { LPG Rinnai R1 - 511E }\end{array}$ \\
\hline Bahan Bakar & $\begin{array}{l}\text { LPG ( Liquid } \\
\text { Petroleum Gas) }\end{array}$ \\
\hline Kapasitas Minyak & 12 Liter \\
\hline Sistem Pendingin & Sirkulasi Air \\
\hline Kapasitas Air Pendingin & \pm 250 Liter \\
\hline Daya & 220 Volt 400 Watt \\
\hline Sistem & $\begin{array}{l}\text { Vacuum Frying } \\
\text { (Menggoreng Dengan } \\
\text { Hampa Udara) }\end{array}$ \\
\hline Penggerak Vakum & 1 inch \\
\hline
\end{tabular}

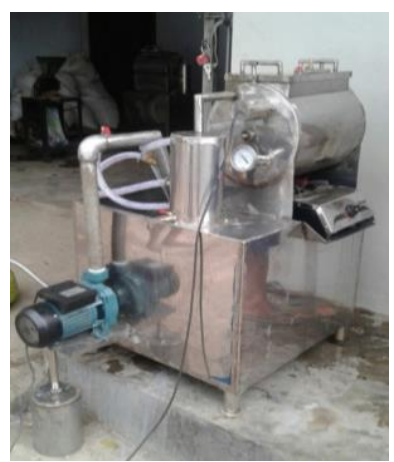

Gambar 1. Mesin Vacuum Frying Kapasitas 2 kg Bahan

Cara Kerja Mesin Vacuum Frying:

- Isi bak air sampai $\pm 3 \mathrm{~cm}$ dari permukaan bak sirkulasi.

- Masukkan minyak goreng ke dalam tabung sampai dasar keranjang buah.

- Pastikan tombol pengendali suhu pada posisi off sewaktu menghubungkan regulator LPG dengan tabung.

- Periksa kedudukan jarum penyetel suhu pada $70^{\circ} \mathrm{C}$ $90^{\circ} \mathrm{C}$, kemudian hubungkan steker boks pengendali suhu dengan listrik 220 volt, minimal 900 Watt.

- Tekan tombol pengendali suhu pada posisi on dan nyalakan kompor gas.

- Setelah tercapai suhu yang di set (ditandai nyala kompor mengecil), masukkan bahan maksimum sebanyak $2 \mathrm{~kg}$ ke dalam keranjang penggoreng kemudian tutup.
- Pasang tutup tabung penggoreng dan kunci rapatrapat, tutup keran pelepas vakum, nyalakan pompa dengan menekan tombol besar dalam posisi on pada boks pengontrol sambil membuka keran sirkulasi air di atas tabung jet, tunggu hingga air keluar dari selang bagian atas kondensor.

- Setelah vacuum meter meter menunjukkan angka $700 \mathrm{mmHg}$, turunkan keranjang ke dalam minyak dengan memutar tuas pengaduk setengah putaran $\left(180^{\circ} \mathrm{C}\right)$. Goyanglah tuas setiap 5 menit untuk meratakan pemanasan.

- Pada saat bahan dimasukkan ke dalam minyak, suhu akan turun, jarum meter vakum bergerak ke kanan, kaca pengintai menjadi berembun.

- Setelah matang, buih pada tabung penggorengan akan hilang (dilihat dari kaca pengintai dengan menekan tombol lampu ke posisi on), angkat bahan ke atas minyak dengan memutar tuas pengaduk $180^{\circ}$ dan kunci. Matikan pompa, kompor, dan keran sirkulasi air, kemudian buka keran pelepas vakum (di atas tutup), hingga vacuum meter menunjuk angka 0 .

- Buka tutup tabung dan keranjang penggoreng, angkat keripik buah dan tiriskan pada mesin pengering.

\section{Bahan penelitian}

Bahan-bahan yang dibutuhkan untuk membuat keripik pisang adalah sebagai berikut:

1. Pisang

Bahan baku dalam pembuatan kripik pisang adalah pisang kepok. Pisang yang dipilih adalah pisang yang sudah tua dan masih mentah (belum matang) sehingga mudah diiris-iris/ dirajang tipis- tipis dan dibentuk sesuai dengan selera konsumen. Syarat Mutu Pisang Kepok Kuning Segar dapat mengacu pada SNI 01 4481 - 1998.

\section{Air Bersih}

Air dalam pembuatan kripik pisang digunakan untuk mencuci pisang. Air yang digunakan harus memenuhi persyaratan air minum dan air bersih sesuai standar Permenkes RI No. 416/MENKES/PERK/IX/90. Air tersebut tidak berwarna, tidak berasa, tidak berbau dan tidak mengandung zat yang membahayakan.

3. Minyak goreng

Minyak goreng yang digunakan adalah minyak kelapa atau minyak kelapa sawit yang bermutu baik (jernih dan tidak tengik), sesuai SNI 01 - 3741 - 2002. Penggunaan minyak goreng dengan kualitas rendah akan menghasilkan kripik yang tidak tahan lama (cepat tengik).

4. Lartan Natrium Bisulfit $\left(\mathrm{Na}_{2} \mathrm{SO}_{3}\right)$ 
Larutan Natrium Bisulfit 0,3\% - 0,5\% digunakan untuk merendam pisang agar tidak terjadi perubahan warna menjadi coklat. Di perdesaan larutan ini dapat diganti dengan potongan-potongan daun sirih.

Dalam pembuatan kripik pisang dapat ditambahkan bahan tambahan pangan (BTP). Tujuan penambahan bahan tambahan pangan ini adalah untuk memperbaiki tekstur, rasa, dan penampakan. Penggunaan bahanbahan tersebut baik jenis maupun jumlahnya harus memenuhi persyaratan yang direkomendasikan. Persyaratan bahan tambahan pangan mengacu pada SNI 01 0222-1995, Bahan yang ditambahkan dalam pembuatan kripik pisang adalah:

1. Gula pasir

Fungsi gula dalam pembuatan kripik pisang adalah untuk memberikan rasa manis. Gula pasir dibuat sirup terlebih dahulu dengan perbandingan $1 \mathrm{~kg}$ gula pasir dilarutkan dalam 5 gelas air. Gula yang digunakan harus bermutu baik, yaitu kering, tidak bau apek atau masam, tidak nampak adanya ampas atau bahan asing dan berwarna putih. Standar gula kristal putih (SNI 013140-2001).

\section{Garam dapur}

Fungsi garam dapur adalah untuk memberi rasa asin. Garam yang digunakan adalah garam beryodium (SNI $01-3556-2000$ ).

\section{Konsep Perancangan Vacuum Frying}

Dibawah ini gambar konsep perancangan mesin vacuum frying:

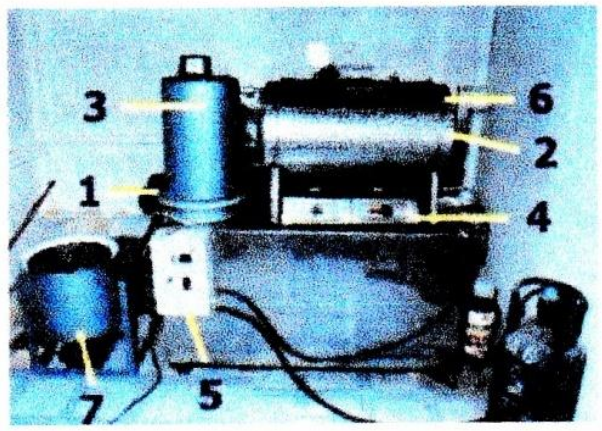

Gambar 2. Mesin Penggoreng Hampa dan

Komponen-Komponennya

(http://www.pustaka.litbang.deptan.go.id/agritek/dkij 0122.pdf)

Bagian-bagian penting dari mesin penggoreng hampa diatas adalah:

1. Pompa Vakum Water jet, berfungsi untuk menghisap udara di dalam ruang penggoreng sehingga tekanan menjadi rendah, serta untuk menghisap uap air bahan.

2. Tabung Penggoreng, berfungsi untuk mengkondisikan bahan sesuai tekanan yang diinginkan. Di dalam tabung dilengkapi keranjang buah setengah lingkaran.

3. Kondensor, berfungsi untuk mengembunkan uap air yang dikeluarkan selama penggorengan. Kondensor ini menggunakan air sebagai pendingin.

4. Unit Pemanas, menggunakan kompor gas LPG.

5. Unit Pengendali Operasi (Boks Kontrol), berfungsi untuk mengaktifkan alat vakum dan unit pemanas.

6. Bagian Pengaduk Penggorengan, berfungsi untuk mengaduk buah yang berada dalam tabung penggorengan.

7. Mesin pengering (spinner), berfungsi untuk meniriskan kripik.

\section{Mekanisme Kerja Vacuum Frying}

Berikut penjelasan mekanisme kerja mesin vacuum frying yang diantaranya:

a. Bahan yang dimasukkan ke dalam penggorengan vacuum akan digoreng secara vacuum. Penggorengan secara vacuum ini akan membuat kadar air di dalam buah akan dikeluarkan dan digantikan oleh minyak. Dengan suhu penggorengan rata-rata yang digunakan berkisar 70 - $90^{\circ} \mathrm{C}$ dan tekanan bisa mencapai $76 \mathrm{cmhg}$, dengan lama penggorengan antara 30 menit sampai 50 menit (perlakuan ini tergantung jenis dan karakteristik buah). Karena setiap buah memiliki kadar air dan tekstur daging buah yang berbeda. Karena penggorengan dengan mesin vacuum frying ini bisa menurunkan titik didih di bawah $90^{\circ} \mathrm{C}$, maka hasil keripik tidak akan sampai gosong.

b. Untuk menggoreng dibutuhkan minyak goreng sekitar 12 liter. Dengan adanya penurunan titik didih di bawah $90^{\circ} \mathrm{C}$ pada penggorengan maka struktur kandungan minyak goreng tidak cepat rusak, sehingga minyak goreng bisa digunakan untuk menggoreng kripik hingga mencapai 100 kali penggorengan. Dengan demikian bisa menghemat penggunaan minyak goreng.

Untuk hasil yang terbaik sebaiknya menggunakan minyak goreng yang bermerk dan jernih, karena minyak goreng yang kualitasnya rendah akan mempengaruhi warna dan aroma keripik buah. Buah yang dibuat dengan mesin vacuum frying bisa bertahan untuk layak konsumsi hingga setengah tahun, dan ini juga tergantung kualitas akan kemasannya.

\section{Proses Pengolahan Keripik Pisang}

Tahapan-tahapan poses yang harus dilakukan dalam pembuatan keripik pisang adalah sebagai berikut: 
a. Pengupasan dan Pengirisan

Pisang dikupas, kemudian diiris tipis-tipis (tebal $2-3$ $\mathrm{mm})$ secara memanjang atau melintang, langsung ditampung dalam bak perendaman untuk menghindari proses oksidasi enzim fenolase yang ada dalam getah pisang.

b. Perendaman

Hasil irisan direndam dalam larutan natrium bisulfit $\left(\mathrm{Na}_{2} \mathrm{SO}_{3}\right)$ 0,3-0,5\% selama 10 menit lalu ditiriskan.

\section{c. Penggorengan}

Irisan buah pisang digoreng menggunakan minyak yang cukup banyak sehingga semua bahan terendam. Tiap $1 \mathrm{~kg}$ irisan pisang membutuhkan 3 liter minyak goreng. Selama penggorengan, dilakukan pengadukan secara pelan-pelan. Penggorengan dilakukan sampai kripik cukup kering dan garing. Hasil penggorengan disebut dengan kripik pisang. Untuk mendapatkan keripik pisang dengan rasa manis dapat dilakukan penaburan dengan gula halus.

d. Penirisan minyak

Hasil penggorengan pertama ditiriskan dengan menggunakan peniris minyak hingga minyak yang ada menetes tuntas.

e. Pemberian Bumbu

Untuk melayani konsumen yang memiliki selera berbeda-beda, dapat diciptakan rasa kripik pisang yang beraneka rasa, misalnya kripik pisang manis, kripik pisang asin, dan kripik pisang pedas.

\section{Rancangan Penelitian Utama}

Adapun variabel yang akan diamati adalah sebagai berikut:

1. Variabel bebas yaitu variabel yang bebas diambil, yang telah ditentukan oleh peneliti. Adapun variabel tersebut adalah suhu dan waktu penggorengan.

2. Variabel terikat (tidak bebas) yaitu variabel yang nilai tergantung dari variabel bebas yang telah ditentukan. Dalam hal ini variabel terikatnya adalah kualitas keripik pisang kepok.

Rancangan penelitian terdiri dari tiga perlakuan dengan dua kali ulangan. Penelitian menggunakan 2 faktor yaitu suhu dan waktu penggorengan dengan tiga kali ulangan. Faktor suhu memiliki 3 taraf (level), yaitu $70^{\circ} \mathrm{C}, 80^{\circ} \mathrm{Cdan} 90^{\circ} \mathrm{C}$. Faktor waktu juga memiliki 3 level, yaitu 30 menit, 40 menitdan 50 menit.

\section{Tahap Penelitian}

Penelitian yang dilaksanakan terdiri dari penelitian pendahuluan dan penelitian utama. Tujuan dari penelitian pendahuluan adalah untuk menentukan rentang suhu dan waktu yang optimal yang digunakan dalam proses penggorengan. Hasil terbaik dari penelitian pendahuluan tersebut digunakan pada penelitian utama.

Penelitian dilakukan dengan 2 tahap yaitu penelitian pendahuluan dan penelitian utama. Penelitian pendahuluan dilakukan untuk mengetahui kisaran suhu dan waktu penggorengan keripik pisang. Pengamatan yang dilakukan pada penelitian pendahuluan adalah pengamatan warna dan kerenyahan keripik pisang secara subjektif.

Percobaan pada penelitian pendahuluan ini akan dilakukan secara trial and error. Pada penelitian pendahuluan dilakukan penggorengan hampa pada suhu $60^{\circ} \mathrm{C}$ hingga $100{ }^{\circ} \mathrm{Cdan}$ waktu penggorengan selama 20 menit hingga 60 menit dengan kapasitas masuk per prosesnya adalah $2 \mathrm{~kg}$. Perlakuan ini dikembangkan lagi pada beberapa taraf pada penelitian utama. Pada penelitian utama, hasil penelitian pendahuluan dikembangkan lebih lanjut pada berbagaitingkat suhu dan waktu. Sehingga suhu dan waktu penggorengan yang terbaik diperoleh dari penelitian pendahuluan ini secara subjektif dari pengamatan warna dan kerenyahan keripik pisangadalah suhu $70^{\circ} \mathrm{C}, 80^{\circ} \mathrm{C}$, dan $90^{\circ} \mathrm{Cdengan}$ waktu selama 30 menit, 40 menit, dan 50 menit.

\section{Teknik Pengambilan Data}

Dalam penelitian ini, peneliti menggunakan observasi langsung untuk teknik pengambilan data dari hasil penelitian yaitu suatu teknik atau metode pengumpulan data dengan cara mengadakan pengamatan secara langsung pada Mesin Vacuum Frying yang diuji dengan mencatat hasil pengamatan.

Penentuan perlakuan suhu dan waktu penggorengan yang terbaik dari hasil uji organoleptikdengan uji pembobotan. Pada uji organoleptik, panelis dimintai pendapatnya mengenai tingkat kesukaannya terhadap produk keripik pisang. Uji organoleptik pada penelitian ini menggunakan 15 orang panelis dengan uji kesukaan meliputi 4 parameter mutu yaitu aroma, rasa, kerenyahan, dan warna.

Panelis diberi kuesioner mengenai parameter organoleptik keripik yaitu warna, rasa, kerenyahan, dan aroma. Lalu panelis diminta untuk mengurut tiap parameter berdasarkan tingkat kepentingannya. 
Pengurutannya mulai dari $4=$ sangat penting, $3=$ penting, $2=$ agak penting, dan $1=$ tidak penting. Formulir uji organoleptik dapat dilihat di bawah ini.

\section{Formulir uji organoleptik keripik pisang}

Nama :

Tanggal Pengujian :

Nyatakan penilaian anda dengan menuliskan skor kesukaan (1 -7) pada kolom berikut.

Keterangan :

$1=$ Sangat tidak suka

2 = Tidak suka

$3=$ Agak tidak suka

$4=$ Netral

$5=$ Agak suka

$6=$ Suka

$7=$ Sangat suka

Tabel 2. Uji Organoleptik Keripik Pisang

\begin{tabular}{|c|c|c|c|c|}
\hline Kode Sampel & Wama & Kerenyahan & Aroma & Rasa \\
\hline A1B1 & & & & \\
\hline A1B2 & & & & \\
\hline A1B3 & & & & \\
\hline A2B1 & & & & \\
\hline A2B2 & & & & \\
\hline A2B3 & & & & \\
\hline A3B1 & & & & \\
\hline A3B2 & & & & \\
\hline A3B3 & & & & \\
\hline
\end{tabular}

\section{Keterangan:}

$\begin{array}{lll}\mathrm{A}=\text { Suhu penggorengan }\left({ }^{\circ} \mathrm{C}\right) & \mathrm{B} & =\text { Waktu penggorengan (meni } \\ \mathrm{A} 1=\text { Suhu } 70^{\circ} \mathrm{C} & \mathrm{B} 1 & =\text { Waktu } 30 \text { menit } \\ \mathrm{A} 2=\text { Suhu } 80^{\circ} \mathrm{C} & \mathrm{B} 2 & =\text { Waktu } 40 \text { menit } \\ \mathrm{A} 3=\text { Suhu } 90^{\circ} \mathrm{C} & \mathrm{B} 3 & =\text { Waktu } 50 \text { menit }\end{array}$

\section{Formulir Kuisioner tingkat kepentingan keripik} pisang

Nama :

Tanggal Penilaian :

Nyatakan penilaian anda terhadap tingkat kepentingan parameter-parameter suatu produk keripik.

Keterangan :

$1=$ Tidak Penting

$2=$ Agak Penting

$3=$ Penting

$4=$ Sangat Penting.

\section{HASIL DAN PEMBAHASAN}

Penelitian ini dilakukan untuk mengetahui pengaruh suhu dan lama penggorengan terhadap parameter mutu dan organoleptik, serta menentukan suhu dan waktu penggorengan yang optimal dilihat dari uji pembobotan.

Uji organoleptik yang digunakan adalah uji hedonik (kesukaan), yang menyangkut penilaian beberapa orang panelis terhadap sifat produk. Dalam uji ini, panelis diminta tanggapannya tentang kesukaan atau ketidak sukaannya. Pengujian ini menggunakan skor dengan tujuh skala kesukaan yaitu 7(sangat suka), 6 (suka), 5 (agak suka), 4 (netral), 3 (agak tidak suka), 2 (tidak suka), dan 1 (sangat tidaksuka). Parameter yang diuji secara organoleptik dari keripik pisang ini adalah rasa, warna, aroma, dan kerenyahan.

Berikut ini adalah tabel data dan grafik uji organoleptik terhadap keripik pisang meliputi:

a. Data organoleptik terhadap rasa keripik pisang

b. Data organoleptik terhadap kerenyahan keripik pisang

c. Data organoleptik terhadap aroma keripik pisang

d. Data organoleptik terhadap warna keripik pisang

e. Hasil uji tingkat kepentingan keripik pisang.

Tabel 3. Data Organoleptik Terhadap Rasa Keripik Pisang Kepok

\begin{tabular}{|c|c|c|c|c|c|c|c|c|c|}
\hline \multirow{3}{*}{ Panelis } & \multicolumn{3}{|c|}{$70^{\circ} \mathrm{C}$} & \multicolumn{3}{|c|}{$80^{\circ} \mathrm{C}$} & \multicolumn{3}{|c|}{$90^{\circ} \mathrm{C}$} \\
\hline & $30^{\prime}$ & $40^{\prime}$ & $50^{\prime}$ & $30^{\prime}$ & $40^{\prime}$ & $50^{\prime}$ & $30^{\prime}$ & $40^{\circ}$ & $50^{\prime}$ \\
\hline & AlB1 & $\mathrm{A} 1 \mathrm{~B} 2$ & AlB3 & $\mathrm{A} 2 \mathrm{~B} 1$ & $\mathrm{~A} 2 \mathrm{~B} 2$ & $\mathrm{~A} 2 \mathrm{~B} 3$ & $\mathrm{~A} 3 \mathrm{~B} 1$ & $\mathrm{~A} 3 \mathrm{~B} 2$ & A3B3 \\
\hline 1 & 3 & 4 & 4 & 3 & 6 & 7 & 4 & 7 & 7 \\
\hline 2 & 3 & 5 & 6 & 4 & 6 & 7 & 7 & 7 & 7 \\
\hline 3 & 6 & 6 & 6 & 7 & 7 & 5 & 7 & 7 & 7 \\
\hline 4 & 2 & 4 & 5 & 4 & 4 & 7 & 6 & 7 & 7 \\
\hline 5 & 3 & 5 & 5 & 5 & 3 & 6 & 4 & 7 & 7 \\
\hline 6 & 3 & 3 & 6 & 6 & 6 & 6 & 6 & 7 & 7 \\
\hline 7 & 2 & 2 & 6 & 2 & 7 & 7 & 7 & 7 & 7 \\
\hline 8 & 4 & 3 & 6 & 3 & 6 & 6 & 6 & 7 & 7 \\
\hline 9 & 5 & 5 & 4 & 4 & 5 & 3 & 5 & 4 & 4 \\
\hline 10 & 2 & 3 & 6 & 6 & 6 & 4 & 5 & 5 & 6 \\
\hline 11 & 3 & 4 & 5 & 3 & 5 & 6 & 4 & 6 & 6 \\
\hline 12 & 3 & 3 & 6 & 3 & 7 & 7 & 6 & 7 & 7 \\
\hline 13 & 2 & 6 & 5 & 2 & 7 & 7 & 3 & 6 & 7 \\
\hline 14 & 5 & 6 & 6 & 5 & 6 & 6 & 7 & 7 & 6 \\
\hline 15 & 2 & 3 & 6 & 3 & 7 & 7 & 4 & 7 & 7 \\
\hline Total & 48 & 62 & 82 & 60 & 80 & 91 & 81 & 98 & 99 \\
\hline Rata- & 3.2 & 4.133 & 5.466 & 4 & 6 & 6.066 & 5.4 & 6.533 & 6.6 \\
\hline
\end{tabular}




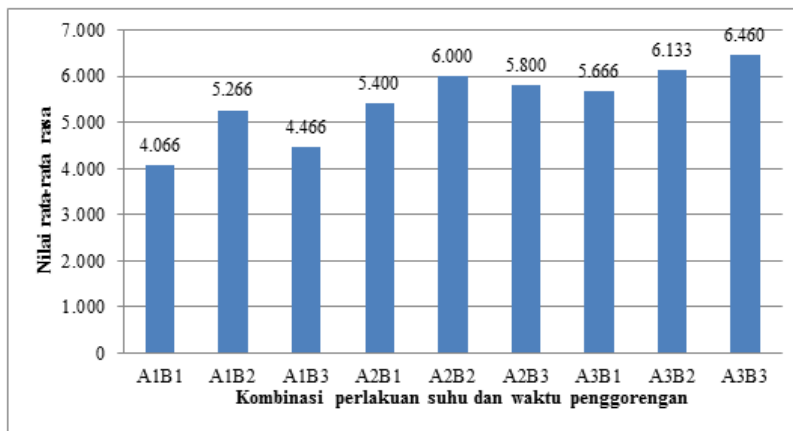

Gambar 3. Grafik Hubungan Pengaruh Suhu dan Waktu Penggorengan Terhadap Penerimaan Rasa Keripik Pisang Kepok

Tabel 4. Data Organoleptik Terhadap Kerenyahan Keripik Pisang Kepok

\begin{tabular}{|c|c|c|c|c|c|c|c|c|c|}
\hline \multirow[b]{2}{*}{ Panelis } & \multicolumn{3}{|c|}{$70^{\circ} \mathrm{C}$} & \multicolumn{3}{|c|}{$80^{\circ} \mathrm{C}$} & \multicolumn{3}{|c|}{$90^{\circ} \mathrm{C}$} \\
\hline & $\begin{array}{c}30^{\prime} \\
\mathrm{A} 1 \mathrm{~B} 1\end{array}$ & $\begin{array}{c}40^{\prime} \\
\mathrm{A} 1 \mathrm{~B} 2\end{array}$ & $\begin{array}{c}50^{\circ} \\
\mathrm{A} 1 \mathrm{~B} 3\end{array}$ & $\begin{array}{c}30^{\prime} \\
\mathrm{A} 2 \mathrm{~B} 1\end{array}$ & $\begin{array}{c}40^{\prime} \\
\mathrm{A} 2 \mathrm{~B} 2\end{array}$ & $\begin{array}{c}50^{\prime} \\
\text { A2B3 }\end{array}$ & $\begin{array}{c}30^{\circ} \\
\mathrm{A} 3 \mathrm{~B} 1\end{array}$ & $\begin{array}{c}40^{\prime} \\
\text { A3B2 }\end{array}$ & $\begin{array}{c}50^{\prime} \\
\mathrm{A} 3 \mathrm{~B} 3\end{array}$ \\
\hline 1 & 3 & 4 & 4 & 3 & 6 & 7 & 4 & 7 & 7 \\
\hline 2 & 3 & 5 & 6 & 4 & 6 & 7 & 7 & 7 & 7 \\
\hline 3 & 6 & 6 & 6 & 7 & 7 & 5 & 7 & 7 & 7 \\
\hline 4 & 2 & 4 & 5 & 4 & 4 & 7 & 6 & 7 & 7 \\
\hline 5 & 3 & 5 & 5 & 5 & 3 & 6 & 4 & 7 & 7 \\
\hline 6 & 3 & 3 & 6 & 6 & 6 & 6 & 6 & 7 & 7 \\
\hline 7 & 2 & 2 & 6 & 2 & 7 & 7 & 7 & 7 & 7 \\
\hline 8 & 4 & 3 & 6 & 3 & 6 & 6 & 6 & 7 & 7 \\
\hline 9 & 5 & 5 & 4 & 4 & 5 & 3 & 5 & 4 & 4 \\
\hline 10 & 2 & 3 & 6 & 6 & 6 & 4 & 5 & 5 & 6 \\
\hline 11 & 3 & 4 & 5 & 3 & 5 & 6 & 4 & 6 & 6 \\
\hline 12 & 3 & 3 & 6 & 3 & 7 & 7 & 6 & 7 & 7 \\
\hline 13 & 2 & 6 & 5 & 2 & 7 & 7 & 3 & 6 & 7 \\
\hline 14 & 5 & 6 & 6 & 5 & 6 & 6 & 7 & 7 & 6 \\
\hline 15 & 2 & 3 & 6 & 3 & 7 & 7 & 4 & 7 & 7 \\
\hline Total & 48 & 62 & 82 & 60 & 80 & 91 & 81 & 98 & 99 \\
\hline $\begin{array}{l}\text { Rata- } \\
\text { Rata }\end{array}$ & 3.2 & 4.133 & 5.466 & 4 & 6 & 6.066 & 5.4 & 6.533 & 6.6 \\
\hline
\end{tabular}

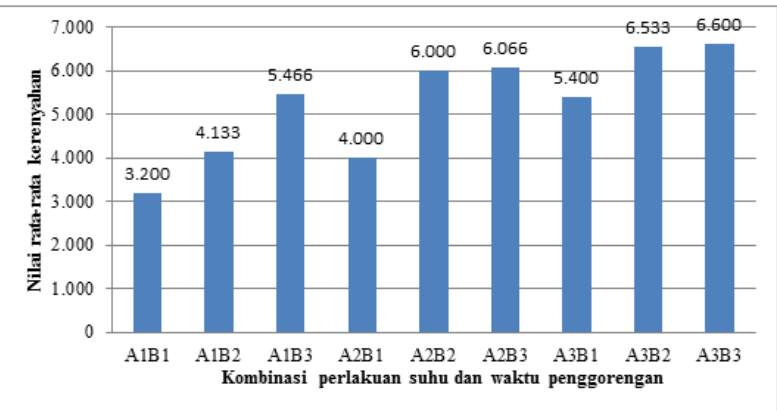

Gambar 4. Grafik Hubungan Pengaruh Suhu dan Waktu Penggorengan Terhadap Penerimaan Kerenyahan Keripik Pisang Kepok

Tabel 5. Data Organoleptik Terhadap Aroma Keripik Pisang Kepok

\begin{tabular}{|c|c|c|c|c|c|c|c|c|c|}
\hline \multirow{3}{*}{ Panelis } & \multicolumn{3}{|c|}{$70^{\circ} \mathrm{C}$} & \multicolumn{3}{|c|}{$80^{\circ} \mathrm{C}$} & \multicolumn{3}{|c|}{$90^{\circ} \mathrm{C}$} \\
\hline & $30^{\prime}$ & $40^{\prime}$ & $50^{\prime}$ & $30^{\prime}$ & $40^{\prime}$ & $50^{\prime}$ & $30^{\prime}$ & $40^{\prime}$ & $50^{\prime}$ \\
\hline & $\mathrm{A} 1 \mathrm{~B} 1$ & $\mathrm{~A} 1 \mathrm{~B} 2$ & AlB3 & $\mathrm{A} 2 \mathrm{~B} 1$ & $\mathrm{~A} 2 \mathrm{~B} 2$ & $A 2 B 3$ & $\mathrm{~A} 3 \mathrm{~B} 1$ & $\mathrm{~A} 3 \mathrm{~B} 2$ & A3B3 \\
\hline 1 & 2 & 6 & 5 & 3 & 3 & 4 & 7 & 5 & 7 \\
\hline 2 & 4 & 5 & 4 & 5 & 5 & 5 & 5 & 6 & 6 \\
\hline 3 & 2 & 3 & 6 & 4 & 7 & 7 & 7 & 7 & 7 \\
\hline 4 & 2 & 4 & 7 & 3 & 5 & 7 & 7 & 7 & 7 \\
\hline 5 & 6 & 3 & 7 & 7 & 7 & 7 & 6 & 7 & 7 \\
\hline 6 & 5 & 5 & 6 & 6 & 6 & 6 & 6 & 6 & 7 \\
\hline 7 & 6 & 7 & 7 & 6 & 5 & 6 & 6 & 7 & 7 \\
\hline 8 & 4 & 6 & 6 & 7 & 7 & 7 & 7 & 7 & 7 \\
\hline 9 & 4 & 6 & 6 & 4 & 4 & 7 & 6 & 7 & 7 \\
\hline 10 & 3 & 7 & 6 & 5 & 6 & 6 & 5 & 6 & 6 \\
\hline 11 & 2 & 7 & 7 & 7 & 7 & 7 & 7 & 7 & 7 \\
\hline 12 & 2 & 6 & 7 & 6 & 6 & 7 & 7 & 7 & 7 \\
\hline 13 & 4 & 7 & 7 & 5 & 7 & 4 & 5 & 4 & 7 \\
\hline 14 & 2 & 5 & 5 & 4 & 5 & 5 & 5 & 5 & 5 \\
\hline 15 & 4 & 5 & 6 & 5 & 5 & 5 & 6 & 6 & 6 \\
\hline Total & 52 & 82 & 92 & 77 & 85 & 90 & 92 & 94 & 100 \\
\hline
\end{tabular}

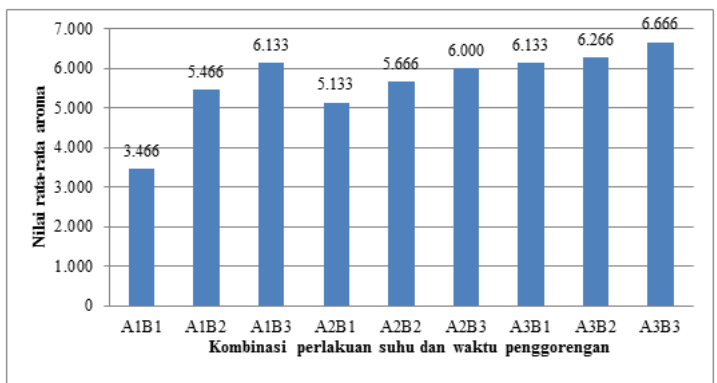


Gambar 5. Grafik Hubungan Pengaruh Suhu dan Waktu Penggorengan Terhadap Penerimaan Aroma Keripik Pisang Kepok

Tabel 6. Data Organoleptik Terhadap Warna Keripik Pisang Kepok

\begin{tabular}{|c|c|c|c|c|c|c|c|c|c|}
\hline \multirow{3}{*}{ Panelis } & \multicolumn{3}{|c|}{$70^{\circ} \mathrm{C}$} & \multicolumn{3}{|c|}{$80^{\circ} \mathrm{C}$} & \multicolumn{3}{|c|}{$90^{\circ} \mathrm{C}$} \\
\hline & $30^{\prime}$ & $40^{\prime}$ & $50^{\prime}$ & $30^{\prime}$ & $40^{\prime}$ & $50^{\prime}$ & $30^{\prime}$ & $40^{\prime}$ & $50^{\prime}$ \\
\hline & $\mathrm{AlBl}$ & $A 1 B 2$ & $\mathrm{~A} 1 \mathrm{~B} 3$ & $\mathrm{~A} 2 \mathrm{~B} 1$ & $\mathrm{~A} 2 \mathrm{~B} 2$ & $\mathrm{~A} 2 \mathrm{~B} 3$ & $\mathrm{~A} 3 \mathrm{~B} 1$ & $\mathrm{~A} 3 \mathrm{~B} 2$ & $\mathrm{~A} 3 \mathrm{~B} 3$ \\
\hline 1 & 3 & 6 & 4 & 5 & 7 & 4 & 6 & 7 & 5 \\
\hline 2 & 5 & 5 & 5 & 5 & 5 & 6 & 5 & 4 & 5 \\
\hline 3 & 5 & 5 & 5 & 5 & 5 & 5 & 5 & 5 & 5 \\
\hline 4 & 6 & 5 & 4 & 5 & 5 & 5 & 5 & 5 & 5 \\
\hline 5 & 5 & 5 & 5 & 6 & 5 & 5 & 5 & 5 & 5 \\
\hline 6 & 3 & 2 & 7 & 5 & 7 & 7 & 7 & 7 & 7 \\
\hline 7 & 5 & 5 & 5 & 7 & 5 & 5 & 5 & 6 & 5 \\
\hline 8 & 3 & 7 & 3 & 5 & 7 & 7 & 3 & 7 & 7 \\
\hline 9 & 3 & 6 & 5 & 5 & 5 & 5 & 5 & 5 & 5 \\
\hline 10 & 4 & 3 & 6 & 5 & 5 & 5 & 4 & 5 & 4 \\
\hline 11 & 5 & 5 & 5 & 4 & 5 & 6 & 5 & 5 & 5 \\
\hline 12 & 5 & 5 & 5 & 3 & 5 & 5 & 4 & 5 & 6 \\
\hline 13 & 7 & 5 & 7 & 6 & 7 & 3 & 5 & 4 & 5 \\
\hline 14 & 7 & 7 & 7 & 7 & 6 & 7 & 7 & 7 & 7 \\
\hline 15 & 7 & 7 & 7 & 5 & 7 & 7 & 7 & 7 & 7 \\
\hline Total & 73 & 78 & 80 & 78 & 86 & 82 & 78 & 84 & 83 \\
\hline
\end{tabular}

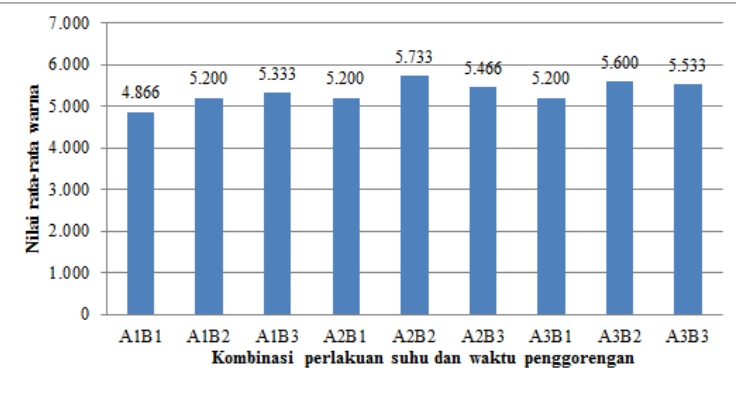

Gambar 6. Grafik Hubungan Pengaruh Suhu dan Waktu Penggorengan Terhadap Penerimaan Warna Keripik Pisang Kepok

\section{Pembahasan}

Tabel 7. Hasil Uji Tingkat Kepentingan Keripik Pisang Kepok

\begin{tabular}{|c|c|c|c|c|}
\hline Panelis & Rasa & Kerenyahan & Aroma & Warna \\
\hline 1 & 4 & 4 & 2 & 1 \\
\hline 2 & 2 & 4 & 4 & 4 \\
\hline 3 & 4 & 4 & 1 & 2 \\
\hline 4 & 4 & 4 & 1 & 3 \\
\hline 5 & 2 & 4 & 3 & 4 \\
\hline 6 & 4 & 4 & 2 & 3 \\
\hline 7 & 3 & 4 & 3 & 1 \\
\hline 8 & 4 & 2 & 2 & 4 \\
\hline 9 & 3 & 3 & 2 & 3 \\
\hline 10 & 2 & 4 & 3 & 4 \\
\hline 11 & 3 & 4 & 2 & 3 \\
\hline 12 & 4 & 3 & 3 & 2 \\
\hline 13 & 2 & 4 & 2 & 4 \\
\hline 14 & 4 & 4 & 1 & 3 \\
\hline 15 & 4 & 4 & 3 & 2 \\
\hline Total & 49 & 56 & 39 & 43 \\
\hline Rata-Rata & 3.266 & 3.733 & 2.6 & 2.866 \\
\hline Bobot (\%) & 32.666 & 37.333 & 26 & 28.666 \\
\hline
\end{tabular}

Uji organoleptik pada penelitian ini menggunakan 15 orang panelis dengan 4 parameter mutu yaitu aroma, rasa, kerenyahan, dan warna. Dapat dilihat pada gambar 19, bahwa produk dengan penerimaan panelis tertinggi untuk rasa terdapat pada perlakuan $90^{\circ} \mathrm{C}$ selama 50 menit sedangkan yang terendah terdapat pada produk dengan perlakuan suhu $70^{\circ} \mathrm{C}$ selama 30 menit. Semakin tinggi suhu dan waktu penggorengan maka penilaian panelis untuk rasa keripik semakin tinggi. Parameter aroma, nilai tertinggi juga terdapat pada produk dengan perlakuan penggorengan $90^{\circ} \mathrm{C}$ selama 50 menit, dan yang terendah terdapat pada produk dengan perlakuan penggorengan pada suhu $70^{\circ} \mathrm{C}$ selama 30 menit. Sedangkan untuk warna, dapat dilihat pada grafik bahwa nilai untuk semua perlakuan tidak jauh beda, dan untuk kerenyahan, nilai tertinggi terdapat pada produk dengan perlakuan penggorengan pada suhu $90^{\circ} \mathrm{C}$ selama 50 menit. Sedangkan yang terendah terdapat pada perlakuan dengan suhu $70^{\circ} \mathrm{C}$ selama 30 menit. Jika dilihat dari grafiknya, semakin tinggi suhu dan waktu penggorengan maka penilaian panelis terhadap kerenyahan semakin tinggi juga. Hal ini sesuai dengan nilai kadar air. Dimana semakin rendah kadar air, panelis semakin menyukai produk tersebut. Artinya semakin rendah kadar air, maka produk tersebut semakin renyah dan semakin banyak 
ruang kosong yang akan diisi oleh minyak. Sedangkan panelis lebih menyukai kerenyahan produk yang waktu penggorengannya selama 50 menit. Begitu juga nilai kerenyahan untuk semua produk dengan perlakuan penggorengan selama 50 menit, hampir tidak jauh beda.

\section{PENUTUP}

\section{Kesimpulan}

Kesimpulan penulis diantaranya sebagai berikut:

1. Perlakuan suhu dan waktu penggorengan yang terbaik untuk pembuatan keripik pisang adalah suhu $90^{\circ} \mathrm{C}$ selama 50 menit.

2. Hasil kuisioner menunjukkan bahwa panelis cenderung mengurutkan rasa pada urutan pertama $(32.666 \%)$, kerenyahan pada urutan kedua $(37.333 \%)$, aroma pada urutan ketiga $(26 \%)$, dan warna pada urutan keempat $(28.666 \%)$.

3. Panelis lebih condong pada nilai kerenyahan.

\section{Saran}

Saran penulis diantaranya sebagai berikut:

1. Perlu dilakukan pengkajian mutu produk keripik pisang yang dihasilkan pada suhu dan waktu penggorengan terbaik.

2. Perlu dilakukan penelitian untuk menentukan jenis kemasan yang tepat agar produk keripik pisang dapat dipertahankan mutunya selama penyimpanan untuk jangka waktu tertentu.

\section{DAFTAR PUSTAKA}

Aguk Dewantara, L0C 009 016, Laporan Tugas akhir. Pengaruh Waktu Penggorengan Vakum Terhadap Kadar air Dan Organoleptik Keripik Kulit Pisang. Program Studi Diploma III Teknik Kimia Program Diploma Fakultas Teknik Universitas Diponegoro Semarang.

Azkenazi N, S Mizrahi dan Z Berk. 1984. Heat and mass Transfer in frying. Di dalam B. M. Mc Kenna (ed.). Engineering and Food Vol. 1. Elsevier Apllied Science Publ., London.

Block, Z. 1964. Frying. Di dalam M.A Joslyn dan J.J Heid (ed). Food Process Operation Vol 3. The AVI Publ. Co., Westport.

Blumenthal MM. and Stier RF. 1991. Optimization off deep fat frying operations. Trend Food Science

Djatmiko B, dan AB Enie.1985. Proses Penggorengan dan Pengaruhnya Terhadap Sifat Fisiko Kimia Minyak dan Lemak. Agro Industri Press.
Jurusan Teknologi Industri Pertanian, Fatetat, IPB, Bogor.

Eva Mayasari. Laporan Praktikum Penggorengan Keripik Buah.

Kamsiati, Elmi. 2010. Peluang Pengembangan Teknologi Pengolahan Keripik Buah Dengan Menggunakan Penggoreng Vakum (Online), (http://ejurnal.lit

bang.pertanian.go.id/index.php/jppp/article/vie wFile/3528/2986) diakses pada tanggal 3 April 2017.

Lastriyanto A.1997. Penggorengan Buah secara Vakum (Vacuum Frying) dengan Menerapkan Pemvakuman Water Jet. Temu Ilmiah serta Ekspos Alat dan Mesin Pertanian. CisaruaBogor, 27 Februari 1997.

Lastriyanto A. 2006. Mesin Penggorengan Vakum (Vacuum Fryer). Malang.

Mahanani HA, Aplikasi Praproses dalam Pembuatan Ripe BananaChip. [Skripsi] Fakultas Teknolog Pertanian Universitas Jember, 2013

Muchtadi TR.2008 . Teknologi Proses Pengolahan Pangan. 3 rd ed. Bogor : Institut Pertanian Bogor.

Nurhayati, Eka Ruriani, Maryanto, Produksi dan Pemasaran RipeBanana Chip di Kabupaten Lumajang. Laporan Pengabdian kepada Masyarakat Program Ipteks bagi Masyarakat. Lembaga Pengabdian kepada Masyarakat universitas Jember Tahun Anggaran 2014.

Ruri Wijayanti, I Wayan Budiastra, Rokhani Hasbullah, Kajian Rekayasa Prose Penggorengan Hampa dan Kelayakan Usaha Keripik Pisang, Jurnal Keteknikan Pertanian, Vol 25, No 2, Oktober 2011.

Sudjud HR. 2000. Mempelajari pengaruh suhu dan waktu penggorengan hampa terhadap sifat fisik dan Organoleptik keripik buah cempedak (Artocarpus integer (Thunb) Merr). Skripisi Fakultas Teknologi Pertanian, IPB, Bogor.

Yuniarto K.. 2007. Korelasi nisbih fraksi kentang terhadap volume minyak dengan penurunan mutu fisik dan kimia minyak selama penggorengan hampa. Jurnal Teknologi Pertanian 8 (2): 103-109.

Gambar dari konsep perancangan: (http://www.pustaka.

litbang.deptan.go.id/agritek/dkij0122.pdf) di akses pada tanggal 3 april 2017. 
